\title{
Technological properties of medium density particleboard produced with soybean pod husk and Eucalyptus wood
}

\author{
Propriedades tecnológicas de painéis de partículas de média densidade \\ produzidos com casca da vagem de soja e madeira de Eucalyptus \\ Douglas Lamounier Faria (1), Ingrid Luz Guimarães² (1), Thais Brito Sousa (1), \\ Thiago De Paula Protásio ${ }^{3}$ (D), Lourival Marin Mendes ${ }^{1}$ (D), José Benedito Guimarães Junior ${ }^{1}$ (1) \\ ${ }^{1}$ Universidade Federal de Lavras - UFLA, Lavras, MG, Brasil \\ Universidade Federal de Goiás - UFG, Jataí, GO, Brasil \\ ${ }^{3}$ Universidade Federal Rural da Amazônia - UFRA, Parauapebas, PA, Brasil
}

\begin{abstract}
How to cite: Faria, D. L., Guimarães, I. L., Sousa, T. B., Protásio, T. P., Mendes, L. M., Guimarães Junior, J. B. (2020). Technological properties of medium density particleboard produced with soybean pod husk and Eucalyptus wood. Scientia Forestalis, 48(126), e3070. https://doi.org/10.18671/scifor.v48n126.19
\end{abstract}

\begin{abstract}
The market for wood-based panels increases annually, which along with the need for proper disposal of agribusiness wastes, justifies the search for alternative materials for new products. The objective of this research was to evaluate the effect of the use of soybean pod husks in the production of Eucalyptus MDP (Medium Density Particleboard). The panels were produced with a nominal density of $0.70 \mathrm{~g} . \mathrm{cm}^{-3}$. The proportions used of soybean pod waste particles compared to those of Eucalyptus in the internal layer were $0,25,50,75$ and $100 \%$. The adhesive used was urea-formaldehyde in the proportion of $10 \%$, for all the layers. The pressing cycle consisted of a temperature of $160^{\circ} \mathrm{C}$ for a period of $15 \mathrm{~min}$ at a pressure of $4 \mathrm{MPa}$. To evaluate the quality of the panels produced their physical and mechanical properties were determined: apparent density; compression ratio; water absorption and thickness swelling at 2 and $24 \mathrm{~h}$ immersion; perpendicular traction; modulus of elasticity and modulus of rupture in static bending. The insertion of soybean pod husks in the MDP caused an increase in the dimensional instability of the panel and a decrease of the mechanical properties. The modulus of elasticity for MDP was in the range of $1842 \pm 184$ to $1111 \pm 187 \mathrm{MPa}$, with $0 \%$ and $100 \%$ soybean pod husks, respectively. Comparisons with the American and Brazilian standards for particleboards were presented, showing the potential for using soybean pod husk as a natural fiber resource for production of MDP. A maximum addition of $6.4 \%$ of soybean pod husks for the production of MDP eucalyptus panels is recommended.
\end{abstract}

Keywords: Agribusiness wastes; Reconstituted wood panels; Alternative material; Particleboards.

\section{Resumo}

O mercado de painéis à base de madeira aumenta anualmente, que juntamente com a necessidade de destinação adequada de resíduos agroindustriais, justifica a busca específica de materiais alternativos para produção de novos produtos. O objetivo deste trabalho foi avaliar o efeito do uso de resíduos de vagem de soja na produção de painéis MDP (Medium Density Particleboard) de Eucalyptus. Os painéis foram produzidos com densidade nominal de $0,70 \mathrm{~g} . \mathrm{cm}^{-3}$. As proporções utilizadas das partículas de resíduo de soja em relação às de Eucalyptus na camada interna foram de 0, 25, 50, 75 e 100\%. O adesivo utilizado foi a uréia-formaldeído na proporção de $10 \%$, para todas as camadas. O ciclo de prensagem consistiu em uma temperatura de $160^{\circ} \mathrm{C}$ por um período de 15 min a uma pressão de $4 \mathrm{MPa}$. Para avaliar a qualidade dos painéis produzidos, foram determinadas suas propriedades físicas e mecânicas: densidade aparente; razão de compactação; absorção de água e inchamento da espessura em imersão

Financial support: None.

Conflict of interest: Nothing to declare.

Corresponding author: douglas.lamounier@yahoo.com

Received: 08 September 2018.

Accepted: 25 July 2019.

Editor: Francides Gomes da Silva Júnior

(c) This is an Open Access article distributed under the terms of the Creative Commons Attribution License, which permits unrestricted use, distribution, and reproduction in any medium, provided the original work is properly cited. 
por 2 e 24 h; tração perpendicular; módulo de elasticidade e módulo de ruptura em flexão estática. A inserção de resíduos no MDP causou um aumento na instabilidade dimensional do painel e a diminuição das propriedades mecânicas. O módulo de elasticidade do MDP variou de $1842 \pm 184$ a $1111 \pm 187 \mathrm{MPa}$, com $0 \%$ e $100 \%$ de casca de vagens de soja, respectivamente. Comparações com as normas americanas para painéis de partículas foram apresentadas, mostrando o potencial para usar casca de vagem de soja como um recurso de fibra natural para produção de MDP. Recomenda-se a adição máxima de 6,4\% de casca vagem de soja na produção de painéis MDP de Eucalyptus.

Palavras-chave: Resíduos agroindustriais; Painéis reconstituídos; Material alternativo; Painéis aglomerados.

\section{INTRODUCTION}

Soybeans are some of the main agricultural products in the world, and Brazil is the second largest producer, with 95.4 million tons produced in the harvest of 2015/2016 (National Supply Company, 2016). About $60 \%$ of the total production obtained of the soybean crop is straw. The processing of soybeans results in a "cleaning waste" which can be used for cattle feed, as a low-cost protein source. However, the great variability in the bromatological composition of this residue hinders the nutritional balance of the diets, becoming a problem of its use for this purpose (Thiago \& Silva, 2003).

The soybean pre-cleaning waste is found in large quantities in the processing industries' courtyard and in the farms dryers, becoming a serious inconvenience if it is not removed to more distant places before the fermentation process begins (Goes et al., 2011). An alternative use for this material is the destination for the production of MDP wood panels (Medium Density Particleboard).

According to Scatolino et al. (2017), the growing concern about the environment and the need to reduce the dependence on wood has awakened the interest for substitute renewable materials which can be used in forest-based industries. In addition, the global market for wood-based panels annually increases, leading to the urge to search for alternatives materials, especially in regions without forests (Taha et al., 2018). The agricultural wastes generated by various crops such as sugarcane (Soares et al., 2017), tomato stalks (Taha et al., 2018), rice husks (César et al., 2017), corn straw (Silva et al., 2015), coffee (Scatolino et al., 2017), coconut fibers (Mesquita et al., 2016) and soy (Martins et al., 2018) can potentially be used in the production of particleboards.

Particleboards may be produced from any lignocellulosic material which provides satisfactory mechanical strength with a predetermined specific mass (Melo et al., 2009). According to Mendes et al. (2012), the panel industry uses wood from planted forests, mainly from the genus Pinus and Eucalyptus. However, the use of the residues generated by the Brazilian agribusiness offers itself as an alternative to meet the demand and diversify the raw material used in these industries. In addition, these wastes can be used as an alternative renewable raw material possibly reducing costs in the production of particleboards in Brazil (Scatolino et al., 2017) with a potential to transform this lignocellulosic materials into products with high added value (Surdi et al., 2019). Currently, the insertion of agribusiness lingocellulosic wastes into the composition of particleboards has been a study object for several researchers, such as Martins et al. (2018), Taha et al. (2018), Soares et al. (2017) and Guimarães Junior et al. (2016); who tested, respectively, the following materials: soybean residues, tomato stalks, sugarcane bagasse and sorghum residues.

Muruganandam et al. (2016) mentioned that there are a number of advantages when using sustainable alternatives in the production of wood panels, and the main factor responsible for the improvement of their properties consists in the uniform distribution of the particles and the adhesive, since the relation between particle and adhesive influences significantly the physical and mechanical properties of the panels.

In this context, the objective of this study was to evaluate the effect of the use of soybean pod husks in the physical and mechanical performances of Eucalyptus MDP (Medium Density Particleboards). 


\section{MATERIAL AND METHODS}

For the production of MDP, soybean pod husk (Figure 1) and Eucalyptus wood were used. The soybean pods were randomly collected from different warehouses of rural properties around the city of Jataí-GO. After the collection, the pods were taken to the Forest Products Laboratory of Federal University of Goiás - Jataí Regional, where the cleaning of the material was performed, which consisted in removing the impurities such as dirt particles, seeds and stems.

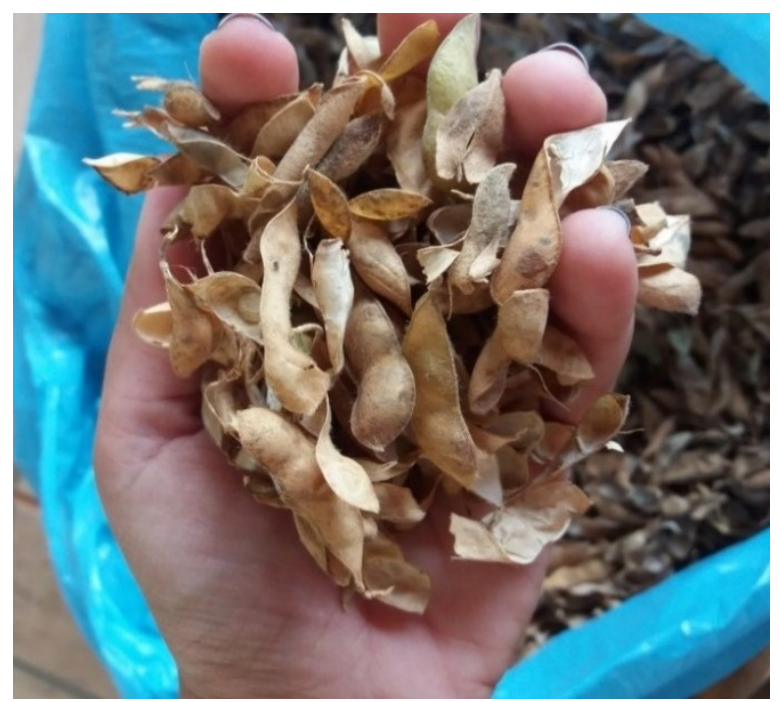

Figure 1. Soybean pod husks used in the production of medium density particleboards.

Eucalyptus grandis wood was obtained from experimental plantings at the Federal University of Lavras - MG. After the collection, the wood was taken to the Experimental Unit of Wood Panels (UEPAM) - UFLA, where it was transformed into sawdust by a hammermill. Afterwards, the particles were stored in plastic bags and transported to the Federal University of Goiás - Jataí Regional.

The dry basis moisture content of the materials used (soybean pods and Eucalyptus wood) was determined by the gravimetric method according to the procedures described by NBR 14929 (Brazilian Association of Technical Standards, 2017a).

The basic density of the soybean pod husks and Eucalyptus wood were determined based on the specifications of NBR 11941 (Brazilian Association of Technical Standards, 2003), and using procedures recommended by Scatolino et al. (2017).

For the chemical analysis, the materials were transformed into sawdust in a knife mill and the particles retained between 40 and 60 mesh sieves were used. The following mentioned standards were used to determine the chemical constituents of the lignocellulosic materials: total extractives content- NBR 14853 (Brazilian Association of Technical Standards, 2010a), insoluble lignin content - NBR 7989 (Brazilian Association of Technical Standards, 2010b); ash content - NBR 13999 (Brazilian Association of Technical Standards, 2017b). The carbohydrate content was obtained by subtracting the sum of the other components considering a total of $100 \%$.

The MDP of three layers were produced. In the covers, thin particles of Eucalyptus wood were used and the core was composed of a mixture of Eucalyptus particles and soybean pod husks. The proportions used of soybean waste particles compared to those of Eucalyptus in the internal layer were, respectively, 0/100, 25/75, 50/50, 75/25 and 100/0, with 3 repetitions (3 panels) per treatment.

To obtain the particles, the soybean pod husks and Eucalyptus grandis wood were processed in a knife mill. The particles obtained were passed through sieves of different granulometry, using for the external layers those retained between the 20 and 40 mesh sieves, 
and for the internal layer those retained between 40 and 60 mesh sieves. The proportion of particles used was of 20/60/20 (external/internal/external) and the nominal density of the MDP was of $0.70 \mathrm{~g} . \mathrm{cm}^{-3}$. For the production of the panels all the particles were dried in an oven with forced air circulation until moisture of $3 \%$, on a dry basis.

The adhesive used was urea-formaldehyde $\mathrm{n}$ in the proportion of $10 \%$, which had a solids content of $63.80 \%$, viscosity of $480 \mathrm{cP}$, gelatinization time of 51 seconds and $\mathrm{pH}$ of 8.55 . Particles mixed with adhesive were taken to a mattress-forming box, with dimensions of $30.0 \mathrm{~cm} \times 30.0 \mathrm{~cm} \times 1.5 \mathrm{~cm}$. The pressing cycle had a temperature of $160^{\circ} \mathrm{C}$ for a period of 15 min at a $4 \mathrm{MPa}$ pressure.

For the tests of water absorption in 2 and 24 hours and thickness swelling in 2 and 24 hours samples of $2.5 \mathrm{~cm} \times 2.5 \mathrm{~cm}$ were used, according to the standard NBR 14810 (Brazilian Association of Technical Standards, 2018). In the tests of perpendicular traction $(5.0 \mathrm{~cm} \times 5.0 \mathrm{~cm})$, modulus of elasticity and modulus of rupture to the static flexion $(25.0 \mathrm{~cm} \times 5.0 \mathrm{~cm})$, the standard DIN 52362 (Normen Für Holzfaserplaten Spanplatten Sperrholz, 1982) was used. Apparent density tests $(5.0 \mathrm{~cm} \times 5.0 \mathrm{~cm}$ ) were performed using standard D1037-12 (American Society for Testing Materials, 2012).The compression ratio was calculated as described by Guimarães Junior et al. (2016) and Scatolino et al. (2017).

The experiment was performed in a completely randomized design, composed of 5 treatments and 3 replications ( 3 panels). The data obtained were analyzed at a 5\% significance level, with help from the software SISVAR 5.6 (Ferreira, 2014). All variables were submitted to the $F$ test by analysis of variance. When the treatments showed a significant difference, simple linear regression models were adjusted to understand the effect of the addition of soybean pod wastes on the physical and mechanical properties of the MDP.

\section{RESULTS AND DISCUSSIONS}

The basic density and the chemical composition of the materials used in the production of MDP are shown in Table 1.

Table 1. Basic density and chemical characteristics of soybean pod husks and Eucalyptus wood.

\begin{tabular}{|c|c|c|c|c|c|}
\hline \multirow{2}{*}{ Material } & \multirow{2}{*}{ Basic density (g.cm-3) } & $\begin{array}{c}\text { Total } \\
\text { extractives }\end{array}$ & $\begin{array}{l}\text { Insoluble } \\
\text { lignin }\end{array}$ & Ash & Carbohydrates \\
\hline & & --.---.- & -.--\%in dry & isis---- & - \\
\hline $\begin{array}{l}\text { Soybean pod } \\
\text { husk }\end{array}$ & $\begin{array}{c}0.200^{\mathrm{b}} \\
(1.3)\end{array}$ & $8.27^{a}(7.65)$ & $23.00^{\mathrm{b}}(2.77)$ & $\begin{array}{l}8.77^{a} \\
(0.57)\end{array}$ & $\begin{array}{l}60.51^{a} \\
(1.86)\end{array}$ \\
\hline $\begin{array}{l}\text { Eucalyptus } \\
\text { wood }\end{array}$ & $\begin{array}{c}0.550^{\mathrm{a}} \\
(2.1)\end{array}$ & $8.14^{a}(15.45)$ & $29.03^{a}(7.18)$ & $\begin{array}{c}0.26^{b} \\
(11.63)\end{array}$ & $\begin{array}{l}62.57^{a} \\
(4.33)\end{array}$ \\
\hline
\end{tabular}

Means followed by the same letter, in the same column, do not differ by the $\mathrm{F}$ test at the $5 \%$ level of significance. Values in parentheses represent the coefficient of variation, in percentage.

Basic density is one of the main variables that influence in the final quality of particleboards. According to Csanády et al. (2015), the eucalyptus wood used presented medium density, since its basic density $\left(0.55 \mathrm{~g} . \mathrm{cm}^{-3}\right)$ is in the range of 0.50 to $0.75 \mathrm{~g} \mathrm{~cm}^{-3}$. The soybean pod husks presented lower basic density than the wood $\left(0.20 \mathrm{~g}^{\mathrm{cm}} \mathrm{cm}^{-3}\right)$. Generally, the lignocellulosic wastes from the agribusiness present low density, being this fact verified for sorghum bagasse - 0.16 g.cm ${ }^{-3}$ (Guimarães Junior et al., 2016); corn straw - $0.17 \mathrm{~g} . \mathrm{cm}^{-3}$ (Silva et al., 2015); sugarcane bagasse - 0.104 to $0.120 \mathrm{~g} . \mathrm{cm}^{-3}$ (Protásio et al., 2013; Soares et al., 2017); rice husks - 0.232 to $0.267 \mathrm{~g} . \mathrm{cm}^{-3}$ (Protásio et al., 2013; César et al., 2017) and soybean pods -0.17 g.cm ${ }^{-3}$ (Martins et al., 2018).

As for the chemical composition of the raw material used in the production of MDP, the extractives are noteworthy, since the high content of certain types of extractives may impair the quality of particleboards. According to Iwakiri (2005), the presence of a great amount of 
extractives in the material used may incur problems on the consumption of adhesives, decrease of mechanical resistance, aside from the occurrence of air bubbles during pressing. However, statistically equal values were found for both materials used, with eucalyptus wood and soybean pod husks, which presented total extractives content of 8.14 and $8.27 \%$, respectively.

Lignin contents found for soybean pods (23.00\%) were lower than for Eucalyptus wood (29.03\%). According to Hillig et al. (2002), the presence of a large amount of lignin in the material can improve the aggregation quality of the particleboards, since these chemicals increase the cohesion and adhesion forces of the particles. Bufalino et al. (2012) reported that particleboards produced with higher content of lignin woods presented better physical and mechanical properties.

The soybean pod husks presented a higher value of ash content $(8.77 \%)$ in comparison to Eucalyptus wood (0.26\%). Silva et al. (2008) found a similar value of ash content for soybean husk, who observed a mean value of $8.90 \%$. The presence of high contents of minerals and some apolar extractives may result in the blocking of chemical groups reactive for adhesion with polar adhesives, affecting the quality of gluing and mechanical performance of particleboards (Ndazi et al., 2007; César et al., 2017). Soares et al. (2017) reported a decrease in perpendicular traction of the particleboards due to the high extractive and ash content and low lignin content of sugarcane bagasse. Similarly, Martins et al. (2018) reported a decrease in perpendicular traction of the particleboards, produced with $0 \%$ to $100 \%$ soybean waste, due to the high extractive content of soybean pods. According to these authors, the higher extractive content impairs resin curing of the board, resulting in weak bonding between particles.

MDP are particleboards which have a density between 0.551 and $0.750 \mathrm{~g} \cdot \mathrm{cm}^{-3} \mathrm{NBR} 14810-$ 2 (Brazilian Association of Technical Standards, 2018), and the panels produced in this work presented values within the expected range (Table 2). There was no significant effect of the addition of soybean pod husk particles in the core of the panels to the apparent density; the mean value was $0.626 \mathrm{~g}_{\mathrm{cm}} \mathrm{cm}^{-3}$. These values were lower than the established nominal density of $0.700 \mathrm{~g}_{\mathrm{cm}} \mathrm{cm}^{-3}$. These results can be attributed to the losses of materials that occur during the handling of the particles in the various production stages of MDP in the laboratory, as happened with Scatolino et al. (2017), Soares et al. (2017) and Martins et al. (2018).

Table 2. Mean apparent density of MDP panels.

\begin{tabular}{cc}
\hline \% Soybean pod husk in the core & Apparent density (g.cm $\left.\mathbf{c m}^{-3}\right)$ \\
\hline 0 & $0.640(0.020) \mathrm{a}$ \\
25 & $0.610(0.037) \mathrm{a}$ \\
50 & $0.630(0.046) \mathrm{a}$ \\
75 & $0.610(0.042) \mathrm{a}$ \\
100 & $0.640(0.024) \mathrm{a}$ \\
Average & 0.626 \\
CV* $\%)$ & 5.61
\end{tabular}

Means followed by the same letter do not differ by the Tukey test at the $5 \%$ level of significance. Values in parentheses refer to the standard deviation of the mean. ${ }^{*}$ Coefficient of variation.

There was an increasing relation between the percentage of soybean pod husks in the board and the compression ratio, which can be visualized in Figure 2 . The increase by the insertion of soybean pod wastes on the board, of the order of $1 \%$, provided an increase of 0.02 in the compression ratio. 


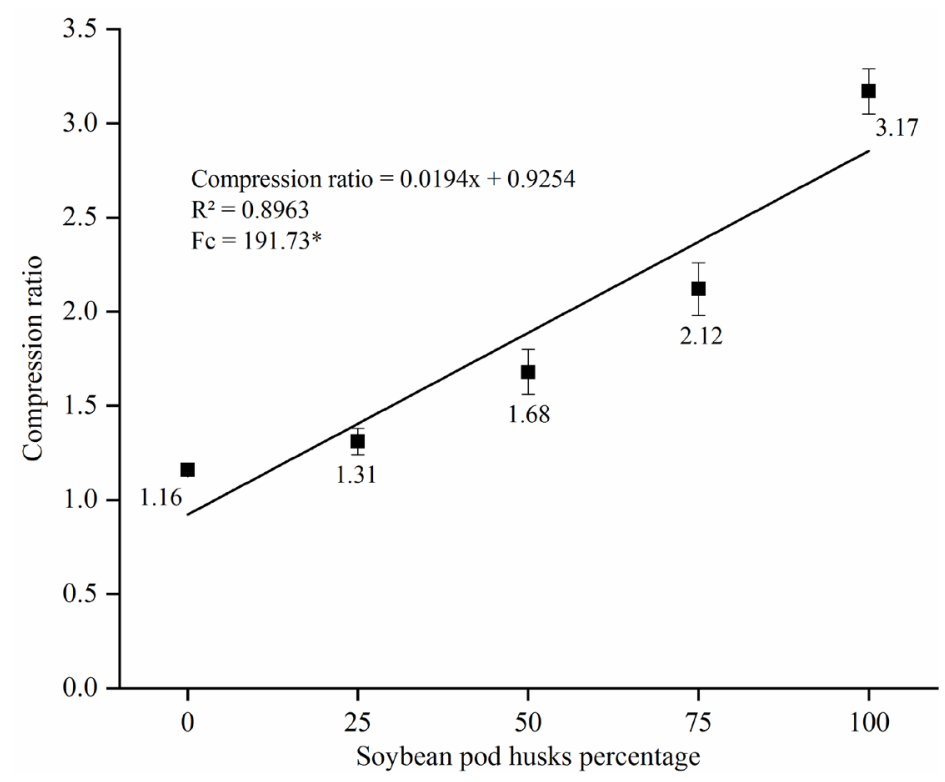

Figure 2. Compression ratio due to the proportion of soybean residue inserted in the MDP panel. *Significant at $5 \%$ level of significance by the $\mathrm{F}$ Test.

The compression ratio of particleboards is related to the density of the raw material, depending also on the humidity of the mattress. As well as the density of the raw material, the density of the panel influences its mechanical properties (Hillig et al., 2002). Due to the lower basic density of the soybean pod husks $\left(0.20 \mathrm{~g}_{\mathrm{cm}} \mathrm{cm}^{-3}\right)$, as the proportion of this residue increased in the panels, there was an increase in the compression ratio values, since lower density materials, compared to higher density ones, require a larger volume of particles to achieve the same density of the particleboard. According to Scatolino et al. (2017), the increased volume of the raw material required may result in a lower amount of adhesive per particle which negatively influences the physical and mechanical properties of the panels.

Adjusted linear regression for water absorption behavior after 2 and $24 \mathrm{~h}$ of water immersion of the panels can be seen in Figures 3 and 4 . The increase in the percentage of soybean husks caused an increase in the water absorption values in the panels. According to Mendes et al. (2012), Scatolino et al. (2013) and Soares et al. (2017), when producing particleboards with lower density materials, a higher number of particles is required compared to higher density materials, which leads to the presence of more hygroscopic sites and, consequently, greater water absorption.

Soares et al. (2017), Scatolino et al. (2017) and Guimarães Junior et al. (2016) when evaluating the physical properties of particleboards produced with agribusiness wastes, observed the same tendency of increase in the water absorption as found in this research, due to the low density of the materials used and, consequently, also increasing the compression ratio. The water absorption after 24 hours of water immersion increased $174 \%$ compared to panels produced with $0 \%$ and $100 \%$ of soybean pod waste. 


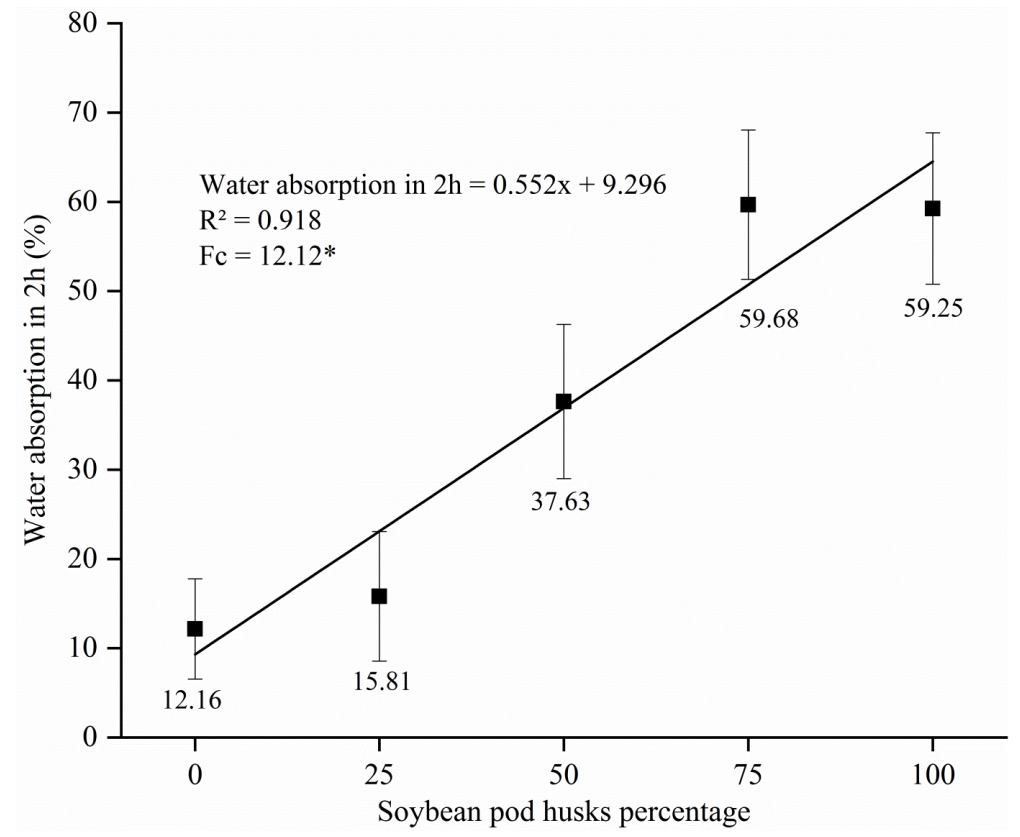

Figure 3. Water absorption in 2 hours of immersion due to the increase in the amount of soybean residue in the panel. * Significant at $5 \%$ level of significance by the $\mathrm{F}$ Test.

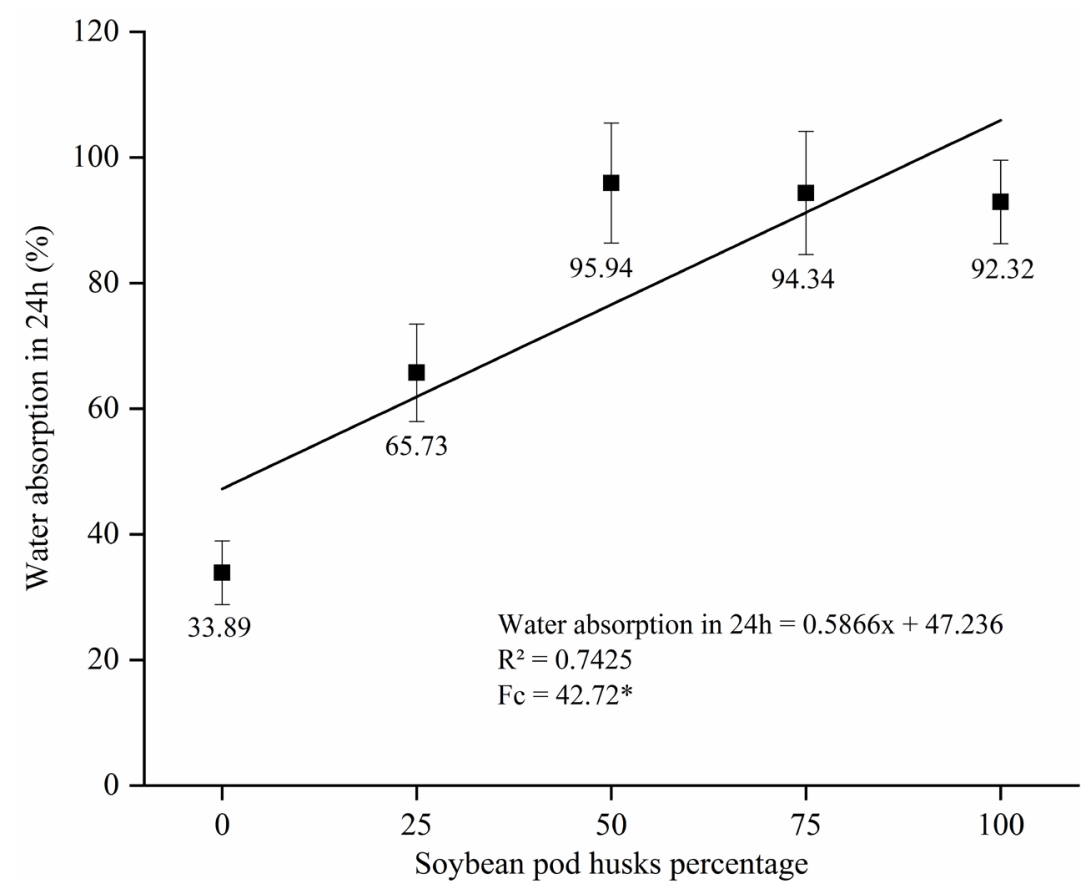

Figure 4. Water absorption in 24 hours of immersion due to the increase in the amount of soybean residue in the panel. *Significant at $5 \%$ level of significance by the $\mathrm{F}$ Test.

In Figures 5 and 6 are the adjusted regressions for the property of swelling in thickness after 2 and $24 \mathrm{~h}$ immersion in water. 


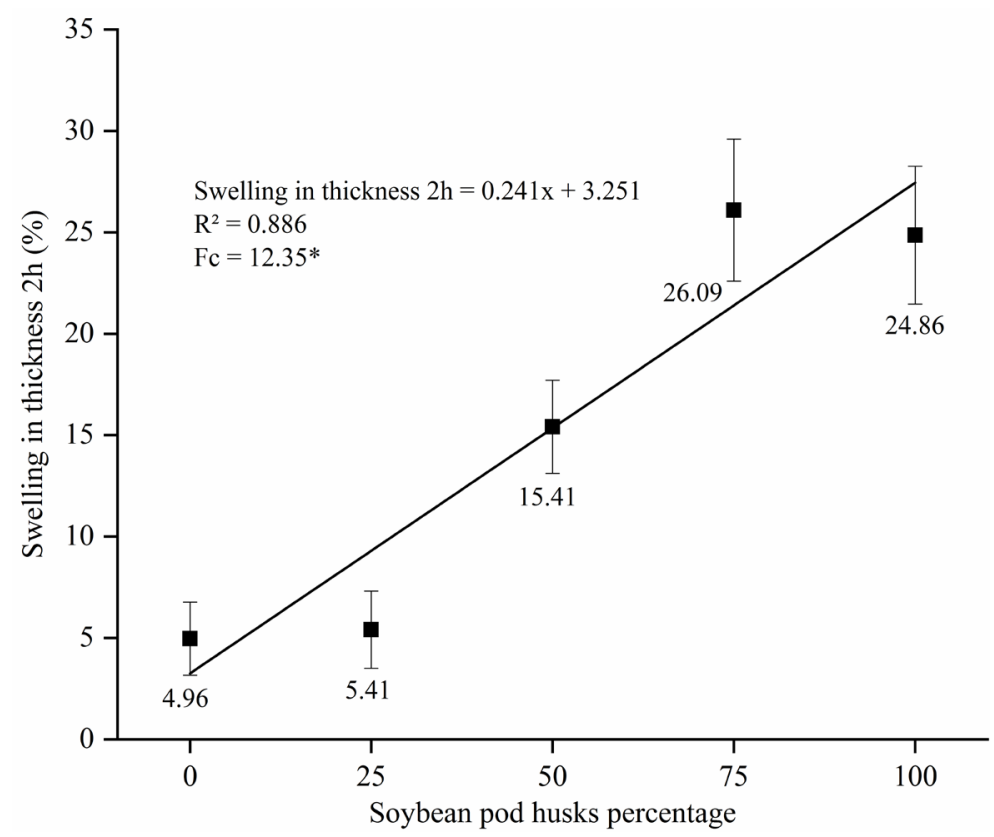

Figure 5. Swelling in thickness after 2 hours of water immersion due to the increase in the amount of soybean residue in the panel. *Significant at $5 \%$ level of significance by the $F$ Test.

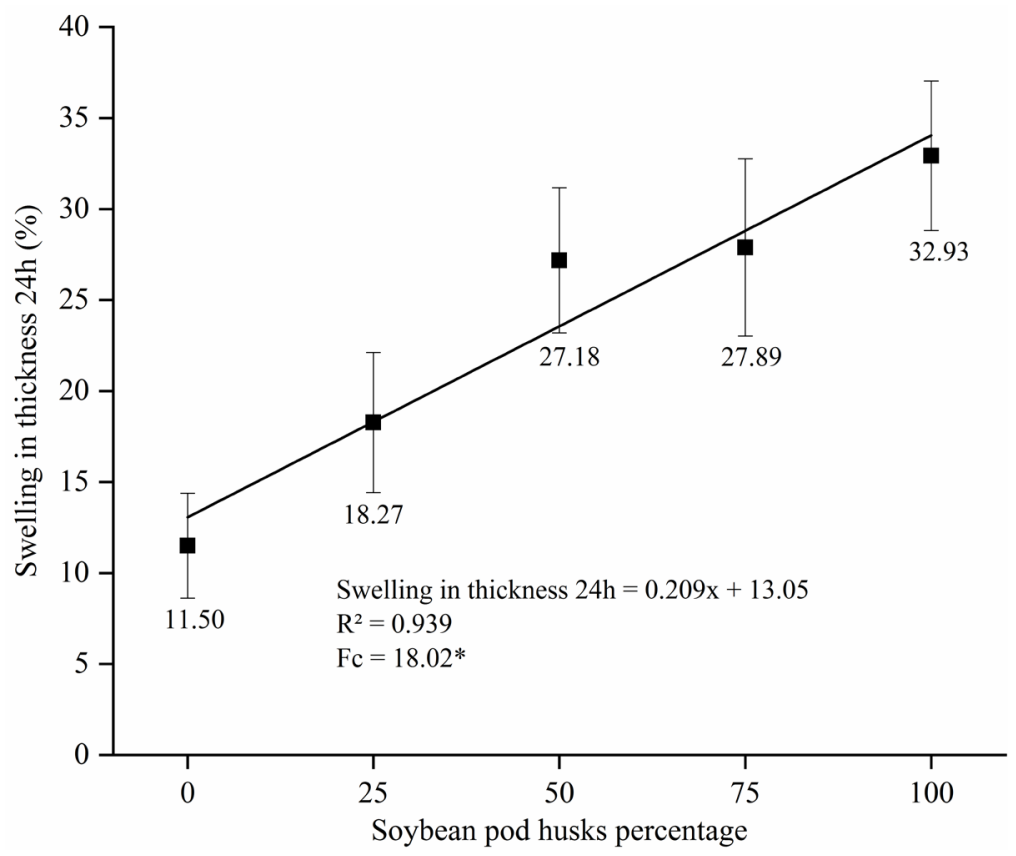

Figure 6. Swelling in thickness after 24 hours of water immersion due to the increase in the amount of soybean residue in the panel. *Significant at $5 \%$ level of significance by the F Test.

According to Iwakiri (2005) and Iwakiri et al. (2012), the increase of the compression ratio from the use of lower density materials results in a higher amount of compacted particles, which release pressing tensions when in contact with water, in addition to providing a higher number of hydroxyl sites to bind with water, causing greater swelling in thickness. Protásio et al. (2012) reported a positive correlation ( $r=0.74)$ swelling between the thickness after $2 \mathrm{~h}$ immersion in water with compression ratio for particleboards of Eucalyptus saligna wood. The higher the amount of soybean pod husks used the greater the swelling in thickness, both in 2 and $24 \mathrm{~h}$ of immersion, of the MDP produced. The increasing trend in the swelling values due to the increase of the lingo-cellulosic wastes in the panels was also described by 
Martins et al. (2018) for conventional particleboards of soybean pod husks with Eucalyptus wood.

The swelling in thickness after 2 hours and 24 hours of water immersion of MDP in this research ranged from 4.96 to $24.86 \%$, with $0 \%$ to $100 \%$ of inclusion of the soybean waste, respectively. On the other hand, the swelling in thickness, after 24 hours of water immersion of MDP in this research ranged from 11.50 to $32.93 \%$. Mendes et al. (2010) when evaluating coffee bark insertion (25\% to $75 \%$ ) in the production of conventional particleboards of Eucalyptus urophylla, with $25 \%$ to $75 \%$ of coffee bark, observed the same increase tendency in the values of swelling in thickness due to the increase in the proportion of the residue; the authors obtained swelling values after 2 and $24 \mathrm{~h}$ of immersion varying between 18.2 and $26.0 \%$ and between 26.2 and 34.00\%, respectively. Similarly, Martins et al. (2018) observed an increase in swelling in thickness of particleboards, after 2 hours (IE2h) and 24 hours (IE24h) of water immersion, with the increased percentage of wood replacement by soybean pod particles. These authors observed that for IE2h and IE24h mean values ranged from 10.38 to $42.78 \%$ and from 15.04 to $53.18 \%$, respectively. This tendency is similar to those observed in this research for MDP (Medium Density Particleboard) produced with soybean pod husk and Eucalyptus wood.

The NBR 14810-2 standard (Brazilian Association of Technical Standards, 2018) establishes the maximum limit of swelling in thickness in $2 \mathrm{~h}$ of immersion in water of $8 \%$. In this sense, equating this value in the obtained equation, it is noticed that the maximum insertion of waste in the panel to meet regulatory requirements is $20 \%$.

For the swelling test in $24 \mathrm{~h}$ immersion in water, there is no maximum limit determined by NBR 14810-2 (Brazilian Association of Technical Standards, 2018). Therefore, EN 312 (European Standard, 2010), which stipulates a maximum of $14 \%$ of swelling in thickness for this type of panel, was used as a reference. In this sense, equating this value in the obtained equation, it is noticed that the maximum insertion of residue in the panel to meet regulatory requirements is $5 \%$. According to the results obtained for water absorption and swelling in thickness, it is noticed that the larger the amount of soybean pod husks present in the core of the panels, the smaller the dimensional stability of the MDP produced.

Figure 7 shows the adjusted regression equation for the property of perpendicular traction found in the different treatments. The perpendicular traction of medium density particleboards in this study ranged from 0.66 to $0.24 \mathrm{MPa}$ for the panel with $0 \%$ and $100 \%$ of soybean wastes, respectively.

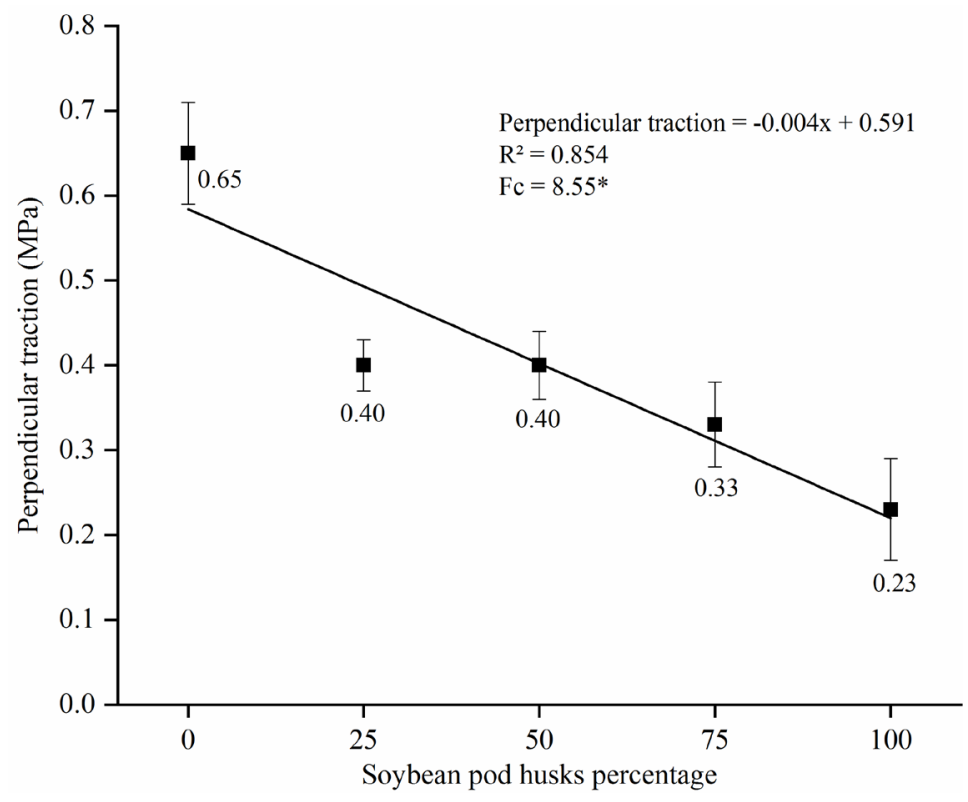

Figure 7. Perpendicular traction according to the increase of the soybean residue ratio in the MDP panel. *Significant at $5 \%$ level of significance by the $\mathrm{F}$ Test. 
The $1 \%$ increase in the amount of soybean pod husks in the panel caused a decrease in perpendicular traction values of $0.004 \mathrm{MPa}$. This phenomenon may have occurred due to the fact that soybean waste has a lower lignin content and a higher ash content. Lignin is a natural adhesive and, therefore, higher contents may lead to better quality (Khedari et al., 2004; Bufalino et al., 2012). Therefore, higher ash contents present higher levels of silica oxide (Dicampos et al., 2008); the presence of higher concentrations of this component and waxes in the soybean pod husks than those in the wood may inhibit or decrease reactive sites for adhesion with polar adhesives, affecting the panel adhesion resistance (Ndazi et al., 2007; Park et al., 2003). According to César et al. (2017), the low lignin and high ash contents found in rice husks negatively influenced particleboard quality, similar to that observed in this study.

Similar results were observed by Silva et al. (2015), when evaluating MDP produced with different percentages of corn straw; they obtained values for this property varying between 0.37 and $0.14 \mathrm{MPa}$, with a decrease of the values as the percentage of the waste on the panels increased from 0 to $100 \%$, relative to the Pinus particles. Likewise, Mendes et al. (2012) found values of perpendicular traction ranging from 0.55 to $0.76 \mathrm{MPa}$, corresponding to Pinus particleboards bonded with formaldehyde urea, with the presence of 75 and $25 \%$ of sugarcane bagasse, respectively.

According to NBR 14810-2 (Brazilian Association of Technical Standards, 2018), medium density particleboards with a thickness between 1.4 and $2.0 \mathrm{~cm}$ must have a minimum perpendicular traction value of $0.35 \mathrm{MPa}$. In this sense, equating this value in the obtained equation, it is noticed that the maximum insertion of residue in the panel to meet regulatory requirements is $60.2 \%$.

Figure 8 and 9 shows the adjusted regressions for the modulus of elasticity and modulus of rupture according to the amount of soybean pod husks in the core of MDP.

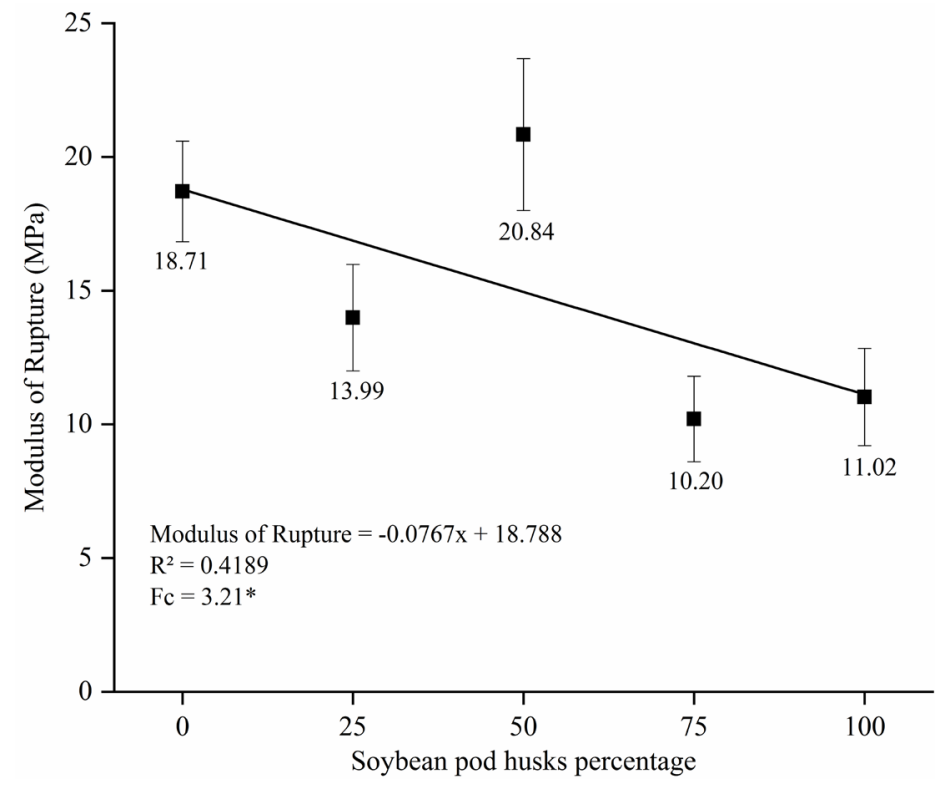

Figure 8. Variation of the modulus of rupture in accordance with the increase in the ratio of soybean pod to the core of the MDP panels. *Significant at $5 \%$ level of significance by the F Test. 


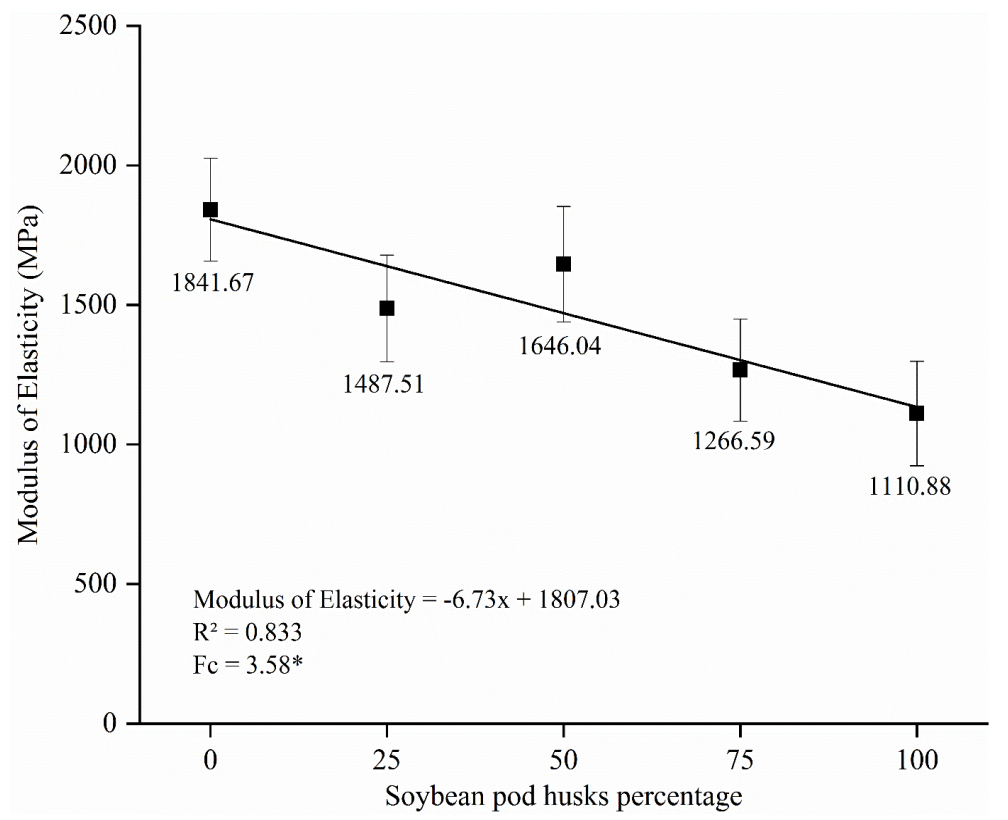

Figure 9. Variation of the modulus of elasticity in accordance with the increase in the ratio of soybean pod to the core of the MDP panels. *Significant at $5 \%$ level of significance by the $\mathrm{F}$ Test.

For the mechanical properties of the static bending test (MOE and MOR) there was a significant effect of the addition of soybean waste in the particleboards. The addition of $1 \%$ of lingocellulosic waste in the panel promotes a reduction of approximately $0.076 \mathrm{MPa}$ for the MOR and of 6.73 MPa for the MOE. The same behavior was observed by several authors when producing particleboards from agribusiness residues such as: Mesquita et al. (2015), when using sisal bundles; Scatolino et al. (2013), working with corn cobs; Mendes et al. (2012) and Soares et al. (2017), with sugarcane bagasse and Melo et al. (2009) and César et al. (2017), with rice husks.

The higher MOR (21 MPa) obtained for the MDP panels produced with $50 \%$ soybean pod husk can be attributed at three probable causes: i) heterogeneity of the lingocellulosic wastes; ii) variability in the application of the adhesive on the particles and, iii) better interaction of the particles due to the increase of the compression ratio. The results indicate that, apparently, the increase of the compression ratio, up to some limits, may benefit the modulus of rupture. For example, Iwakiri et al. (2018) observed that particleboards of Pinus taeda, with higher compression ratio (1.6), presented higher MOR (16 MPa) compared to panels produced with denser woods and lower compression ratio.

The NBR 14810-2 standard (Brazilian Association of Technical Standards, 2018) establishes that MDP panels, with a thickness between 1.4 and $2.0 \mathrm{~cm}$, must have a minimum MOR value of $16 \mathrm{MPa}$. To meet this standard it would be possible to use the maximum amount of $36.35 \%$ of soybean pod husks. According to the American National Standard Institute - ANSI A208.1 (American National Standard Institute, 1993) American standard, particleboards must have minimum values of $11.3 \mathrm{MPa}$ and $1764 \mathrm{MPa}$ for MOR and MOE, respectively. According to the adjusted equation, it would be possible to insert at most 97.63 and $6.4 \%$ of soybean pods in the panels to meet the ANSI standard for MOR and MOE, respectively.

\section{CONCLUSIONS}

The insertion of soybean residue in the internal layer of medium density particleboard caused an increase in water absorption, swelling in thickness and decrease in mechanical properties (MOE, MOR and perpendicular traction). The maximum recommended soybean pod husk amount for MDP was $5.0 \%$ (in mass), based on the standards for the physical properties. For the mechanical properties it is possible to apply up to $6.4 \%$ (in mass). 
Comparisons with the American and Brazilian standards for particleboards show the potential for the use of soybean pod husks as a natural particle resource for production of MDP and an alternative material for the market for wood-based panels in Brazil.

\section{ACKNOWLEDGMENTS}

The authors express their sincere thanks to FAPEMIG, to CNPq (process number 446605/2014-0) and to CAPES for funding the project and/or granting scholarships to the authors. These resources were fundamental to the development of the research.

\section{REFERENCES}

American National Standard Institute - ANSI. (1993). ANSI-A208.1: Mat-formed wood particleboard: Specification.(7 p.) Gaithersburg.

American Society for Testing Materials - ASTM. (2012). D1037-12: Standard methods of evaluating the properties of wood-base fiber and particle materials (32 p.). Philadelphia.

Brazilian Association of Technical Standards - ABNT. (2003). NBR11941: Wood - Determination of basic density (6 p.). São Paulo.

Brazilian Association of Technical Standards - ABNT. (2010a). NBR14853: Determination of soluble matter in ethanol-toluene and in dichloromethane and in acetone (3 p.). São Paulo.

Brazilian Association of Technical Standards - ABNT. (2010b). NBR7989: Pulp and wood - Determination of acid-insoluble lignin (6 p.). São Paulo.

Brazilian Association of Technical Standards - ABNT. (2017a). NBR14929: Wood - Determination of moisture of chips - Method by drying in oven-dried (3 p.). Rio de Janeiro.

Brazilian Association of Technical Standards - ABNT. (2017b). NBR13999: Paper, board, pulps and wood Determination of residue (ash) on ignition at $525^{\circ} \mathrm{C}$ (5 p.). São Paulo.

Brazilian Association of Technical Standards - ABNT. (2018). NBR14810-2: Medium density particleboards Part 2: Requirements and test methods (71 p.). São Paulo.

Bufalino, L., Albino, V. C. S., Sá, V. A., Corrêa, A. R. R., Mendes, L. M., \& Almeida, N. A. (2012). Particleboards made from Australian red cedar: processing variables and evaluation of mixed species. Journal of Tropical Forest Science, 24(2), 162-172.

César, A. A. S., Bufalino, L., Mendes, L. M., Mesquita, R. G. A., Protásio, T. P., Mendes, R. F., \& Andrade, L. M. F. (2017). Transforming rice husk into a high-added value product: potential for particle board production. Ciência Florestal, 27(1), 303-313. https://doi.org/10.5902/1980509826468

Csanády, E., Magoss, E., \& Tolvaj, L. (2015). Quality of Machined Wood Surfaces (257 p.). Switzerland: Springer. http://dx.doi.org/10.1007/978-3-319-22419-0.

Di Campos, M. S., Barbosa, N. P., \& Savastano Júnior, H. (2008). Swine deep bedding ashes as a mineral additive for cement based mortar. Scientia Agrícola, 65(2), 109-115. http://dx.doi.org/10.1590/S010390162008000200001.

European Standard. (2010). EN312: Particleboards - Specifications. English version (22 p.). Brussels: CEN.

Ferreira, D. F. (2014). Sisvar: a Guide for its Bootstrap procedures in multiple comparisons. Ciência e Agrotecnologia, 38(2), 109-112. http://dx.doi.org/10.1590/S1413-70542014000200001.

Goes, R. H. T. B., Patussi, R. A., Souza, K. A., Oliveira, E. R., Gressler, M. G. M., \& Lima, H. L et al. (2011). Chemical composition and in situ ruminal degradability of residue from soybean dryer precleaning. PUBVET, 5(30), 1-13.

Guimarães Junior, J. B., Xavier, M. M., Santos, T. S., Protásio, T. P., Mendes, R. F., \& Mendes, L. M. (2016). Addition of sorghum culture waste in eucalyptus particleboards. Brazilian Journal of Forestry Research, 36(88), 435-442. https://doi.org/10.4336/2016.pfb.36.88.1036

Hillig, E., Haselein, C. R., \& Santini, E. J. (2002). Mechanical Properties of Flakeboard made from Pine, Eucalypts and Wattle wood. Ciência Florestal, 12(1), 59-65. http://dx.doi.org/10.5902/198050981701.

Iwakiri, S. (2005). Panels wood reconstituted. Curitiba: FUPEF.

Iwakiri, S., Trianoski, R., Nascimento, C. C., Juízo, C. G. F., Lengowski, E. C., Bilcati, G. K., \& Gonçalves, T. (2018). Particleboard manufactured from six species of Amazon tropical timbers. Madera y Bosques, 24(3), e243371. http://dx.doi.org/10.21829/myb.2018.243371 
Iwakiri, S., Vianez, B. F., Weber, C., Trianoski, R., \& Almeida, V. C. (2012). Evaluation of the properties of particleboard made from sawmill waste of nine tropical wood species of Amazon. Acta Amazonica, 42(1), 59-64. http://dx.doi.org/10.1590/S0044-59672012000100007.

Khedari, J., Nankongnab, N., Hirunlabh, J., \& Teekasap, S. (2004). New low-cost insulation particleboards from mixture of durian peel and coconut coir. Building and Environment, 39(1), 59-65. http://dx.doi.org/10.1016/j.buildenv.2003.08.001.

Martins, E. H., Vilela, A. P., Mendes, R. F., Mendes, L. M., Vaz, L. E. V. S. B., \& Guimarães Júnior, J. B. (2018). Soybean waste in particleboard production. Ciência e Agrotecnologia, 42(2), 186-194. http://dx.doi.org/10.1590/1413-70542018422015817.

Melo, R. R., Santini, E. J., Haselein, C. R., \& Stangerlin, D. M. (2009). Properties of wood and rice husk particleboard in different proportions. Ciência Florestal, 19(4), 449-460. https://doi.org/10.5902/19805098899

Mendes, R. F., Mendes, L. M., Guimarães Junior, J. B., Mori, F. A., \& César, A. A. S. (2010). Effect of the incorporation of coffee husks on the physico-mechanical properties of Eucalyptus urophylla S.T. Blake particleboards. Ciência e Agrotecnologia, 34(3), 610-617. http://dx.doi.org/10.1590/S141370542010000300012.

Mendes, R. F., Mendes, L. M., Guimarães Júnior, J. B., Santos, R. C., \& César, A. A. S. (2012). Association effect of sugar cane bagasse, type and levels of adhesive on particleboard production. Ciência Florestal, 22(1), 161-170. https://doi.org/10.5902/198050985088

Mesquita, R. G. A., Marconcini, J. M., Sanadi, A. R., César, A. A. S., Tonoli, G. H. D., Venas, T. M., \& Mendes, L. M. (2016). Coir and sisal fibers as fillers in the production of eucalyptus medium density particle boards -MDP. Materials Research, 19(6), 1429-1436. http://dx.doi.org/10.1590/1980-5373-mr-20160361.

Mesquita, R. G. A., Mendes, L. M., Mendes, R. F., Tonoli, G. H. D., \& Marconcini, J. M. (2015). Inclusion of sisal bundles in the production of eucalyptus MDP panels. Scientia Forestalis, 43(105), 75-82.

Muruganandam, L., Ranjitha, J., \& Harshavardhan, A. (2016). A review report on physical and mechanical properties of particle boards from organic waste. International Journal of Chem Tech Reserarch, 9(1), 64-72.

National Supply Company - CONAB. (2016). Acompanhamento da safra brasileira: Grãos - Safra 2015/16 Décimo Segundo Levantamento (Vol. 3, n. 12, 82 p.). Brasília: CONAB.

Ndazi, B. S., Karlsson, S., Tesha, J. V., \& Nyahumwa, C. W. (2007). Chemical and physical modifications of rice husks for use as composite panels. Composites. Part A, Applied Science and Manufacturing, 38(3), 925-935. http://dx.doi.org/10.1016/j.compositesa.2006.07.004.

Normen Für Holzfaserplaten Spanplatten Sperrholz - DIN. (1982). DIN 52362: Testing of wood chipboards bending test, determination of bending strength (p. 39-40). Berlin.

Park, B., Wi, S. G., Lee, K. H., Singh, A. P., Yoon, T., \& Kim, Y. S. (2003). Characterization of anatomical features and silica distribution in rice husk using microscopic and micro-analytical techniques. Biomass and Bioenergy, 25(3), 319-327. http://dx.doi.org/10.1016/S0961-9534(03)00014-X.

Protásio, T. P., Bufalino, L., Tonoli, G. H. D., Guimarães Junior, M., Trugilho, P. F., \& Mendes, L. M. (2013). Brazilian lignocellulosic wastes for bioenergy production: characterization and comparison with fossil fuels. BioResources, 8(1), 1166-1185. http://dx.doi.org/10.15376/biores.8.1.1166-1185.

Protásio, T. P., Guimarães Junior, J. B., Mendes, R. F., Mendes, L. M., \& Guimarães, B. M. R. (2012). Correlations between physical and mechanical properties of particleboards from different Eucalyptus species. Floresta e Ambiente, 19(2), 123-132. http://dx.doi.org/10.4322/floram.2012.014

Scatolino, M. V., Costa, A. O., Guimarães Junior, J. B., Protásio, T. P., Mendes, R. F., \& Mendes, L. M. (2017). Eucalyptus wood and coffee parchment for particleboard production: physical and mechanical properties. Ciência e Agrotecnologia, 41(2), 139-146. http://dx.doi.org/10.1590/141370542017412038616.

Scatolino, M. V., Silva, D. W., Mendes, R. F., \& Mendes, L. M. (2013). Use of maize cob for production of particleboard. Ciência e Agrotecnologia, 37(4), 330-337. http://dx.doi.org/10.1590/S141370542013000400006.

Silva, A. M., Bentes, M. A., Medrado, S. B., \& Carvalho Júnior, J. A. (2008). Study of the biomass application in partial substitution in the coal blends used in the CSN coke production. Revista Tecnologia em Metalurgia e Materiais, 5(1), 40-45. http://dx.doi.org/10.4322/tmm.00501008.

Silva, D. W., Farrapo, C. L., Ribeiro, D. P., Mendes, R. F., Mendes, L. M., \& Scolforo, J. R. S. (2015). MDP with particles of eucalyptus and corn straw. Scientia Forestalis, 43(108), 853-862. 
Soares, S. S., Guimarães Júnior, J. B., Mendes, L. M., Mendes, R. F., Protásio, T. P., \& Lisboa, F. J. N. (2017). Valorization of sugarcane bagasse for production of low density particle boards. Brazilian Journal of Wood Science, 8(2), 64-73. http://dx.doi.org/10.15210/cmad.v8i2.10589

Surdi, P. G., Bortoletto Júnior, G., Castro, V. R., Brito, F. M. S., Berger, M. S., \& Zanuncio, J. C. (2019). Particleboard production with residues from mechanical processing of Amazonian woods. Revista Árvore, 43(1), e430102. http://dx.doi.org/10.1590/1806-90882019000100002.

Taha, I., Elkafafy, M. S., \& Mously, H. E. (2018). Potential of utilizing tomato stalk as raw material for particleboards. Ain Shams Engineering Journal, 9(4), 1457-1464. http://dx.doi.org/10.1016/j.asej.2016.10.003.

Thiago, L. R. L. S., \& Silva, J. M. (2003). Soybean in cattle feed. Technical Circular. Embrapa.

Author's contributions: DLF: conceptualization, investigation, data curation, writing - original draft, writing review \& editing. ILG, TBS: conceptualization, data curation, methodology. TPP, LMM and JBGJ: methodology, supervision, writing - original draft, resources, project administration. 